\title{
Effectiveness of Diffusion Tensor Imaging in the Microstructural Evaluation of Corpus Callosum and Brain Parenchyma in Children with Neurofibromatosis Type I
}

\author{
Nörofibromatosis Tip 1'li Çocuklarda Korpus Kallozum ve Beyin Parankiminin \\ Mikroyapısal Değerlendirilmesinde Difüzyon Tensör Görüntülemenin Etkinliği
}

(i) Dilek Hacer ÇEŞME

Bezmialem Vakıf University Faculty of Medicine, Department of Radiology, İstanbul, Turkey

\section{ABSTRACT}

Objective: To compare tractional anisotropy (FA) and mean diffusivity (MD) values obtained from corpus callosum (CC), basal ganglion, thalamus, frontal and parietal white matter in NF1 patients compared to the control group and to investigate the correlation with CC volume.

Methods: Thirty three cases diagnosed with NF1 and 21 healthy control groups were included in the study. CC volume was measured in both groups. Using tensor imaging (DTI), MD and FA values were calculated from CC genu and splenium, globus pallidum, caudate nucleus, putamen, thalamus, parietal and frontal white matter.

Results: CC volume increased significantly in cases with NF1. There was a significant difference in MD and FA values obtained from $\mathrm{CC}$ genu and splenium compared to the control group. MD values obtained from frontal and parietal white matter, globus pallidum, putamen, thalamus and caudate nucleus were significantly higher than the control group. FA values decreased in caudate nucleus and putamen while FA values in globus pallidum were higher than control group. There was a negative correlation between CC volume and $\mathrm{MD}$ values obtained from KK splenium, putamen, thalamus and caudate nucleus

Conclusion: Increased MD in areas of involvement in NF1 cases can be explained by impaired myelination and demyelination. Heterogeneity in FA values suggests that it is caused by

\section{Öz}

Amaç: NF1'li olgularda korpus kallozum (KK) hacmi ile bazal ganglionlar, talamus, frontal ve parietal beyaz cevherden elde olunan fractional anisotropy (FA) ve mean diffusity (MD) değerlerinin sağlıklı kontrol grubu ile farklılık gösterip göstermediğinin araştırılmasıdır.

Yöntemler: NF1 tanısı almış 33 olgu ve 21 sağlıklı kontrol grubu çalışmaya dahil edildi. Her iki grupta KK hacmi ölçüldü. Difüzyon tensör görüntüleme (DTG) ile KK genu ve splenium, globus pallidum, kaudat nükleus, putamen, talamus, parietal ve frontal beyaz cevherden MD ve FA değerleri hesaplanarak karşılaştırma yapildı.

Bulgular: NF1'li olgularda KK hacmi belirgin artmıştı. KK genu ve spleniumdan elde olunan $\mathrm{MD}$ ve FA değerlerinde kontrol grubuna göre anlamlı farklılık saptandı. Frontal ve parietal beyaz cevher, globus pallidum, putamen, talamus ve kaudat nukleus MD değerleri kontrol grubuna göre anlamlı yüksekti. Kaudat nükleus ve putamende FA değerleri azalırken, globus pallidum FA değerleri ise kontrol grubuna göre yüksekti. KK hacmi ile KK splenium, putamen, talamus ve kaudat nükleus MD değerleri arasında negatif korelasyon vardi.

Sonuç: NF1'li olgularda tutulum alanlarında MD artışı miyelinizasyonda bozulma ve demiyelinizasyon ile açıklanabilir. FA değerlerindeki heterojenite miyelin kılıflarının parçalanması

Address for Correspondence: Dilek Hacer ÇEŞME, Bezmialem Vakıf University Faculty of Medicine, Department of Radiology, İstanbul, Turkey

E-mail: dhcesme@bezmialem.edu.tr ORCID ID: orcid.org/0000-0002-3869-0524

Received: 09.05.2020

Accepted: 01.06.2020

Cite this article as: Çeşme DH. Effectiveness of Diffusion Tensor Imaging in the Microstructural Evaluation of Corpus Callosum and Brain Parenchyma in Children with Neurofibromatosis Type I. Bezmialem Science 2021;9(2):171-6. 
microstructural differences resulting from the breakdown of myelin sheaths or axonal disruption in different locations of the brain. In cases with NF1, DTI findings will help us to understand the occurrence of the disease and the physiopathology of clinical findings in more detail.

Keywords: Neurofibromatosis type I, corpus callosum, diffusion tensor imaging, MD, FA veya aksonal bozulmaya bağlı mikroyapısal değişiklikler sonucu görülebilir. NF1'li olgularda DTG bulguları hastalığın gelişim sürecini ve klinik bulguların fizyopatolojisini daha detaylı anlamamıza yardımcı olacaktır.

Anahtar Sözcükler: Nörofibromatozis tip 1, korpus kallosum, difüzyon tensor görüntüleme, $\mathrm{MD}$, FA

\section{Introduction}

Neurofibromatosis type 1 (NF1) is a neurocutaneous syndrome known as von Recklinghausen's disease. It is caused by mutation or deletion in the $N F 1$ gene on the $17^{\text {th }}$ chromosome, which is inherited autosomal dominantly and results in decreased production of neurofibromin, a tumor suppressor protein $(1,2)$. Diagnostic criteria of NF1 are; cafe-au lait macules, neurofibromas, freckles in the axillary or inguinal areas, optic path gliomas, Lisch nodules, bone lesions, central nervous system neoplasms, cognitive problems and learning difficulties (1).

Hamartomatous lesions observed as hyperintense on T2-weighted images in the brain parenchyma are called unidentified bright objects (UBOs). The most common areas of involvement are; globus pallidum, brainstem, thalamus, cerebellum and subcortical white matter. The prevalence of UBOs in childhood varies between $55-90 \%$ (3). Although the structure of hamartomas is not fully understood; it is known that heterotopia, gliosis, intramyelinic edema, atypical glial infiltrates, microcalcification foci, and even dysplasia are transformed into low-grade astrocytomas and as a result, spongy or vacuolar change develops in the white matter $(2,4,5)$.

The corpus callosum (CC) is the largest commissure in the human brain and is responsible for the communication between both hemispheres. Macrocephaly has been reported in 38\% of the patients with NF1 (6). Although the pathogenesis of CC enlargement in patients with NF1 is not clearly understood yet; it is thought that it may be associated with abnormal neurofibromin and Ras protein activity $(4,6)$. It is thought to be associated with an increase in axon size and number due to myelin disorder $(4,6)$.

Diffusion Tensor Imaging (DTI) shows the relationship between white matter structures and neural functions. Both mean diffusity (MD) and fractional anisotropy (FA) values provide information about microstructural changes in white matter. It provides useful information in detecting abnormalities in white matter structures and in white matter commissures such as corpus callosum in children with NF1 (1).

In our study, we aimed to compare CC volume and FA and MD values obtained from basal ganglia, thalamus, frontal and parietal white matter in patients with NF1 with healthy control group and to investigate the relationship between them.

\section{Methods}

Thirty three patients (22 males and 11 females, mean age; $8.87 \pm 3.44)$ who were followed up with a diagnosis of NF1, and 21 age-matched healthy controls (10 males and 11 females, mean age; 9.61 \pm 4.20 ) were included in this retrospective study. Ethical approval was obtained from our institution. Routine MRI was applied to all patients with NF1 and control group. The following parameters were used in the imaging protocol; Axial and sagittal T2 images (TR/TE: 4,280/91 ms matrix: 384x211; NSA: 1; slice thickness $5 \mathrm{~mm}$ ), axial T1 images (TR/TE: 500/87 ms; matrix: 256x125; NSA: 1; slice thickness $5 \mathrm{~mm}$ ), axial and coronal FLAIR images (TR/TE/TI: 8.000/118/23.687 ms; NSA: 1; slice thickness $5 \mathrm{~mm}$ ), contrast-enhanced axial and coronal T1 images (TR/TR: 448/87; matrix: 256x134; NSA: 1), and 3D T1 postcontrast sagittal images (R/TE: 476/86; matrix: 256x154; NSA: 1; slice thickness $1 \mathrm{~mm}$ ). In 3D T1 images, the boundaries of CC with region of interest (ROI) were drawn manually from a total of 3 sections on the midsagittal line. The CC volume was measured with the aid of a Siemens Syngo-via workstation (Figure 1). DTIs were obtained in the axial plan and



Figure 1. In post-contrast 3D T1 images, the corpus callosum boundaries are determined with ROI and its volume is measured

ROI: Region of interest 
the protocol determined was applied ( $\mathrm{TR}=6,000 \mathrm{~ms}, \mathrm{TE}=89 \mathrm{~ms}$, 30 directional, $\mathrm{b}=1000 \mathrm{~s} / \mathrm{mm}^{2}, 5-\mathrm{mm}$ section thickness, $230 \mathrm{~mm}$ FOV and matrix: 128x128). MD and FA values were calculated by placing ROI on CC genu and splenium, caudate nucleus, globus pallidum, putamen, thalamus, frontal white matter and parietal white matter in Siemens Leonardo workstation (Figures $2 \mathrm{a}$ and $2 \mathrm{~b})$.

\section{Statistical Analysis}

All statistical analyzes were performed with IBM SPSS 19.0. Whether the groups showed normal distribution was evaluated with the Kolmogirov-Smirnov test. Comparisons between the patients with NF1 and the healthy control group were made using the Mann-Whitney U test. The correlation between the CC volume and DTI parameters was investigated with Spearman's correlation test. $\mathrm{P}$ values less than 0.05 were considered significant.

\section{Results}

The MD and FA values and CC volumes in different localizations of the brain belonging to the patients with NF1 and the healthy control group are presented in Table 1.

There was a significant difference between the $\mathrm{CC}$ volume of the patients with NF1 and the healthy control group. CC volume was larger in patients with NF1 $(\mathrm{p}=0.01)$.

The MD and FA values obtained from the CC genu and splenium in patients with NF1 showed a significant difference compared to the control group ( $\mathrm{p}<0.001$ for each). MD and FA values were higher in patients with NF1.

In patients with NF1, MD values obtained from frontal and parietal white matter appearing normal were significantly higher than healthy controls ( $\mathrm{p}<0.001$ for each). However, there was no significant difference between FA values in both locations.

Globus pallidum, putamen, thalamus and caudate nucleus MD values were significantly higher than the control group $(\mathrm{p}<0.001$ for each).

There was a significant difference in globus pallidum, putamen and caudate nucleus FA values of patients with NF1 compared with the healthy control group $(\mathrm{p}=0.047, \mathrm{p}=0.001$, and $\mathrm{p}=0.003$, respectively). While FA values decreased in the caudate nucleus and putamen, globus pallidum FA values were higher in patients with NF1 than in the control group.

There was a negative correlation between CC volume and MD value of putamen, thalamus, caudate nucleus and $\mathrm{CC}$ splenium in patients with NF1 ( $\mathrm{p}=0.015, \mathrm{r}=-0.418, \mathrm{p}=0.010, \mathrm{r}=-0.444$; $\mathrm{p}=0.004, \mathrm{r}=-0.491, \mathrm{p}=0.001$, and $\mathrm{r}=-0.600$, respectively).

\section{Discussion}

The UBOs begin to be seen in the childhood age group, especially at the age of 3 , and continue to increase in number and size until the end of the first decade. They become invisible radiologically as spontaneously regressing from the second decade (7). The loss of signal increases in T2-weighted images with age may reflect

Table 1. The MD and FA values and corpus callosum volumes in different localizations of the brain belonging to the patients with NF1 and the healthy control group

\begin{tabular}{|c|c|c|}
\hline & $\begin{array}{l}\text { Patients with NF1 } \\
(n=33)\end{array}$ & $\begin{array}{l}\text { Control } \\
(n=21)\end{array}$ \\
\hline CC volume & $12.97 \pm 3.30$ & $10.44 \pm 2.87$ \\
\hline CC genu FA & $699.51 \pm 66.33$ & $430.66 \pm 171.32$ \\
\hline CC splenium MD & $901.90 \pm 60.43$ & $700.09 \pm 76.24$ \\
\hline Frontal white matter FA & $331.18 \pm 73.45$ & $352.14 \pm 93.80$ \\
\hline Parietal white matter MD & $917.24 \pm 81.09$ & $722.52 \pm 37.08$ \\
\hline Parietal white matter FA & $368.54 \pm 79.56$ & $350.90 \pm 92.78$ \\
\hline Globus pallidum MD & $834.27 \pm 78.04$ & $657.14 \pm 68.39$ \\
\hline Thalamus MD & $876.84 \pm 53.54$ & $698.38 \pm 59.83$ \\
\hline Thalamus FA & $311.60 \pm 76.50$ & $349.04 \pm 102.11$ \\
\hline Caudat nucleus MD & $814.69 \pm 44.86$ & $711.57 \pm 64.57$ \\
\hline Caudat nucleus FA & $240.42 \pm 104.49$ & $304.23 \pm 63.54$ \\
\hline
\end{tabular}




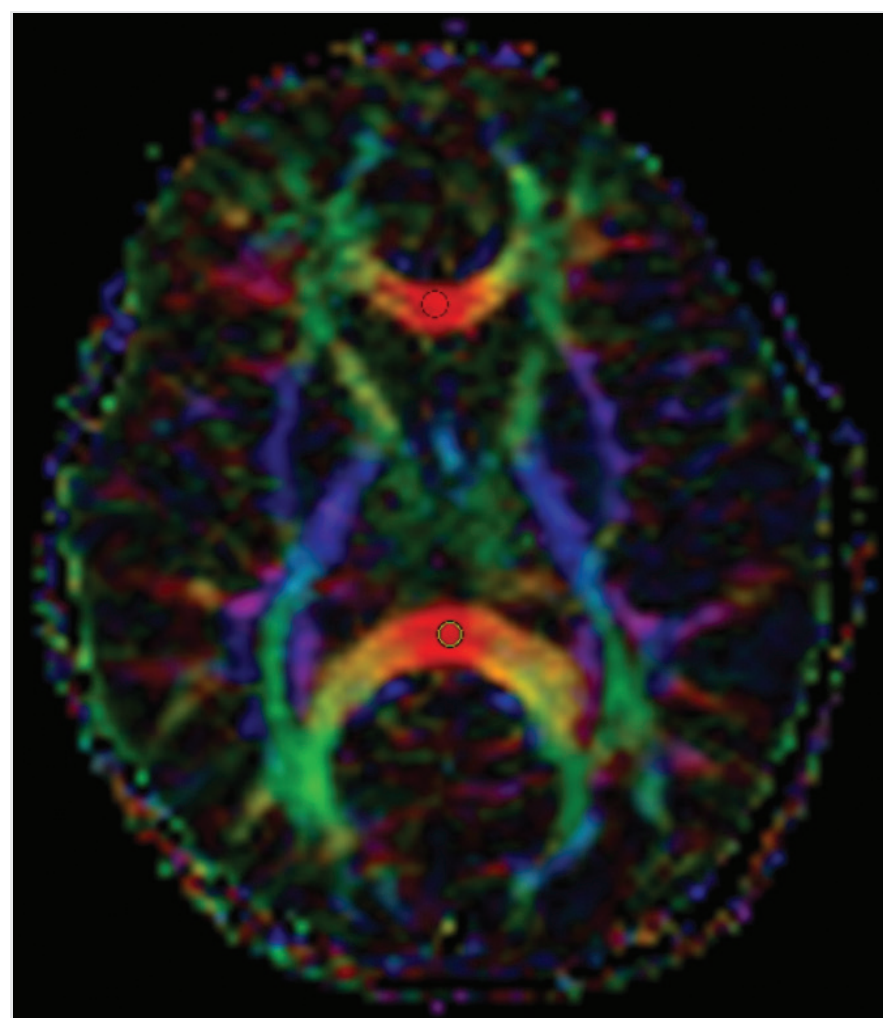

the change in the water content of the brain parenchyma (2). Considering the available pathological data on NF1, it is seen that there is a relationship between UBOs and myelin vacuoles, which can represent evidence of the demyelination process (2). The lesions appearing hyperintense in T2-weighted series represent focal areas with severe disease within the areas showing diffuse myelin disorder.

The CC is the largest axonal pathway in the central nervous system. It provides interhemispheric integration, which is an important function for creativity and intelligence (8). When the CC reaches adult size is controversial. In some studies, it has been reported that growth continues until the age of 15 (8). The generally accepted theory is; it slows down after a rapid growth in the first 4 years of life, and it becomes compatible with the size of adult age group at the age of 10-12. The topography of the $\mathrm{CC}$ is well defined. Fibers from the inferior frontal lobes and inferior parietal lobes pass through the CC genu. The fibers in the remaining parts of the frontal and parietal lobes pass through the CC body. Temporal and occipital lobe fibers intersect in the splenium (8).

It has been shown that the increased total brain volume in patients with NF1 is primarily due to the increase in white matter volume. The expanded CC volume in patients is generally greater than the increase in brain volume (1). Structural brain abnormalities such as enlargement of the CC in children with NF1 have been associated with cognitive impairment (1). In our study, the CC volume increased significantly compared to the control group. Total volume was measured without dividing the CC into sections. While the $\mathrm{CC}$ volume in the age-matched healthy control group was $10.44 \pm 2.87 \mathrm{~cm}^{3}$, it was $12.97 \pm 3.30 \mathrm{~cm}^{3}$ in the patients with NF1. One of the most likely explanations for CC enlargement in children with NF1 is the production of more commissural fibers due to delay or decrease in apoptosis $(6,8,9)$. The decrease in apoptotic process is due to the relation between the regulation of the NF1 gene product neurofibromin and the Ras protein activation pathway. Activated Ras proteins have been shown to have beneficial or harmful effects in the regulation of apoptosis depending on cell type and other factors (8). Other possible causes have been reported as excessive myelination, increased extracellular fluid, vacuolar myelinopathy, increased axon number and width, and/or a combination of these factors $(1,10)$.

It is known that there is a negative relationship between CC enlargement and IQ $(1,3,6,11)$. Pride et al. (11) found a relationship between the enlargement of the $\mathrm{CC}$ body and isthmus and decreased cognitive performance. Contrary to this hypothesis, Kayl et al. (12) claimed that children with more attention problems had a smaller total CC area. Aydin et al. (4) reported that the $\mathrm{CC}$ genu may be affected more in children with NF1 with neurocognitive disabilities. In general, the anterior part of the CC is often enlarged in children, while the posterior and isthmus parts of the adult patients with NF1 are predominantly enlarged (6). 
DTI is an advanced neuroimaging method used to obtain FA and MD maps of white matter pathways. Mutations in NF1 cause microstructural changes in white matter, resulting in motor and cognitive dysfunctions (3). FA is the quantitative measurement of the diffusion of water molecules along the axon direction. It is a very sensitive but nonspecific indicator of the microstructure of white matter. FA reflects fiber density, axonal diameter and myelination in white matter. MD values increase with increasing tissue fluid amount such as inflammation or edema, and MD values decrease with hypercellularity $(4,13)$. In demyelinating diseases, loss of normal myelin structure and axonal loss increase MD by causing enlargement of the extracellular space. The high MD values in UBOs indicate a relatively high molecular movement in these regions compared to the normal brain parenchyma (2). Detection of higher MD values in regions with UBO in patients with NF1 compared to regions without UBO supports the hypothesis that the microstructure of the brain tissue is impaired due to fluid accumulation and vacuolization (3).

Decrease in FA and increase in MD in patients with NF1 indicate disruption of myelin sheaths and/or axonal disruption (10). Diffusion changes result from myelin disorder (7). Sheikh et al. (14) reported that the number and/or size of myelin vacuoles were increased. Alkan et al. (2) stated that it might be related with demyelination. Eastwood et al. (15) explained it with myelin disorders such as demyelination or increased myelin turnover with decreased amount of myelin. However, the observed changes in brain diffusion appear more likely to indicate dysmyelination in patients with NF1. Zamboni et al. (7) claimed that it was the result of widespread and fundamental changes in the cerebral microstructure caused by the underlying gene mutation. In our study, MD values obtained from the CC genu and splenium were significantly higher. We thought that the changes in the CC microstructure such as disruption in myelinization, demyelination, axonal loss and fluid accumulation in the extracellular space caused increase in MD values, as in UBOs in patients with NF1. In addition, frontal and parietal white matter MD values were significantly higher. Despite the normal appearance of white matter, high MD values might be associated with demyelination. Likewise, the detection of high $M D$ values in the basal ganglia (caudate nucleus, putamen, globus pallidum) and thalamus could be explained by the disruption of myelin structure and demyelination. In our study, while CC volume increased in patients with NF1, MD values decreased in the putamen, caudate nucleus and CC splenium . One of the most important hypotheses explaining CC enlargement in patients with NF1 is the production of more commissural fibers due to delay or decrease in apoptosis. The result of this is an increase in the size and number of axons due to myelin disorder. We think that as the $\mathrm{CC}$ volume increases, the relative MD decrease in spenlium, putamen and caudate nucleus can be explained by this hypothesis.

FA can be affected by factors such as axon packing, relative membrane permeability of water, internal axon structure, myelination, and tissue water content $(16,17)$. It is not possible to eliminate the possibility of the anatomical changes due to the dominance of white matter tracts or gray matter in the studied areas, varying intensity of microstructural damage, and regional differences. In patients with NF1, the decrease in FA values may indicate general microstructural changes and dysmyelination $(7,16)$. Increased FA has been associated with decreased axonal caliber and increased axonal density (4). In a study, it was reported that the decrease in FA values in the $\mathrm{CC}$ genu in adult patients with NF1 may have been caused by disruptions in axon or myelin and the decrease in the density of myelinated axons (1). Low FA in any white matter region indicates a decreased myelin content and therefore less efficient axonal transmission (3). In our study, the FA values of the CC genu and splenium were significantly higher than in the patients with NF1 than the healthy control group. This increase in FA could be explained by decreased axonal caliber and increased axonal density in CC.

The thalamus has widespread connections with many cortical regions and enables different sensory inputs to be transmitted and transformed to the cortex (18). The nuclei of the thalamus play a role in sensory and motor information, memory and executive functions, and it has been shown that there is impairment in the integration of these competencies in patients with NF1 (1821). The caudate nucleus is the nucleus of the basal ganglia and plays a role in sensorimotor coordination and targeted behaviors $(18,22)$. It is widely associated with the frontal lobe and especially the dorsolateral prefrontal cortex, which plays a role in working memory and executive function. Demyelination in the thalamus and basal ganglia due to the disruption of myelin structure can be explained by the presence of clinical symptoms that develop in patients with NF1. In our study, there were significant differences in terms of FA values in the basal ganglia between the patients with NF1 and the healthy control group. In patients with NF1, FA values in the caudate nucleus and putamen decreased, while FA values in globus pallidum were higher than in the healthy control group. The decreased FA values observed in the caudate nucleus and putamen suggested dysmyelination due to microstructural changes. The decreased FA values in the basal ganglia supported the view that the disruption in the axon or myelin may have resulted from decrease in the density of myelinated axons. In our study, increased FA values in the globus pallidum may be associated with the revitalization of an area with myelin impairment or with intramyelinic edema and microcalcification secondary to the repair process (16). We are of the opinion that the hyperintensity that occurs in T1-weighted images, especially during the remyelination phase, may be related to myelin repair and microcalcification. Especially in the basal ganglia, the heterogeneity due to increased and decreased FA values supports the view that it may be due to the presence of microstructural differences caused by fragmentation of myelin sheaths or axonal disruption (3).

\section{Study Limitations}

The first limitation of our study was the low number of patients. The second limitation was that clinical and neurocognitive tests were not performed in patients with NF1 and the correlation between CC volume and DTI findings were not investigated. 
Our third limitation was that DTI measurements were made using manual ROI. Using voxel-based measurement methods would minimize the margin of error.

\section{Conclusion}

Our findings showed that the increase in MD values observed in patients with NF1 might be due to impaired myelinization, demyelination, axonal loss and fluid accumulation in the extracellular space. The heterogeneity in FA values suggested that it was caused by microstructural differences that occured as a result of myelin sheaths or axonal disruption in different locations of the brain. We believe that DTI findings obtained in patients with NF1 will help us to understand the formation of the disease and the physiopathology of clinical findings in more detail at the microstructural level.

\section{Ethics}

Ethics Committee Approval: No: 2020/7229.

Informed Consent: Informed consent was not obtained as the study design was retrospective.

Peer-review: Externally peer reviewed.

Financial Disclosure: The author declared that this study received no financial support.

\section{References}

1. Filippi CG, Watts R, Duy LA, Cauley KA. Diffusion-tensor imaging derived metrics of the corpus callosum in children with neurofibromatosis type I. AJR Am J Roentgenol 2013;200:44-9.

2. Alkan A, Sigirci A, Kutlu R, Ozcan H, Erdem G, Aslan M, et al. Neurofibromatosis type 1: diffusion weighted imaging findings of brain. Eur J Radiol 2005;56:229-34.

3. Payne JM, Moharir MD, Webster R, North KN. Brain structure and function in neurofibromatosis type 1: current concepts and future directions. J Neurol Neurosurg Psychiatry 2010;81:304-9.

4. Aydin S, Kurtcan S, Alkan A, Guler S, Filiz M, Yilmaz TF, et al. Relationship between the corpus callosum and neurocognitive disabilities in children with NF-1: diffusion tensor imaging features. Clin Imaging 2016;40:1092-5.

5. Alkan A, Sarac K, Kutlu R, Yakinci C, Sigirci A, Aslan M, et al. Proton MR spectroscopy features of normal appearing white matter in neurofibromatosis type 1. Magn Reson Imaging 2003;21:1049-53.

6. Wignall EL, Griffiths PD, Papadakis NG, Wilkinson ID, Wallis LI, Bandmann O, et al. Corpus callosum morphology and microstructure assessed using structural MR imaging and diffusion tensor imaging: initial findings in adults with neurofibromatosis type 1. AJNR Am J Neuroradiol 2010;31:856-61.

7. Zamboni SL, Loenneker T, Boltshauser E, Martin E, Il'yasov KA. Contribution of diffusion tensor MR imaging in detecting cerebral microstructural changes in adults with neurofibromatosis type 1. AJNR Am J Neuroradiol 2007;28:773-6.
8. Dubovsky EC, Booth TN, Vezina G, Samango-Sprouse CA, Palmer $\mathrm{KM}$, Brasseux CO. MR imaging of the corpus callosum in pediatric patients with neurofibromatosis type 1 . AJNR Am J Neuroradiol 2001;22:190-5.

9. Moore BD 3rd, Slopis JM, Jackson EF, De Winter AE, Leeds NE. Brain volume in children with neurofibromatosis type 1: relation to neuropsychological status. Neurology 2000;54:914-20.

10. van Engelen SJ, Krab LC, Moll HA, de Goede-Bolder A, Pluijm SM, Catsman-Berrevoets CE, et al. Quantitative differentiation between healthy and disordered brain matter in patients with neurofibromatosis type I using diffusion tensor imaging. AJNR Am J Neuroradiol 2008;29:816-22.

11. Pride N, Payne JM, Webster R, Shores EA, Rae C, North KN. Corpus callosum morphology and its relationship to cognitive function in neurofibromatosis type 1. J Child Neurol 2010;25:834-41.

12. Kayl AE, Moore BD 3rd, Slopis JM, Jackson EF, Leeds NE. Quantitative morphology of the corpus callosum in children with neurofibromatosis and attention-deficit hyperactivity disorder. J Child Neurol 2000;15:90-6.

13. Wang L, Goldstein FC, Veledar E, Levey AI, Lah JJ, Meltzer CC, et al. Alterations in cortical thickness and white matter integrity in mild cognitive impairment measured by whole-brain cortical thickness mapping and diffusion tensor imaging. AJNR Am J Neuroradiol 2009;30:893-9.

14. Sheikh SF, Kubal WS, Anderson AW, Mutalik P. Longitudinal evaluation of apparent diffusion coefficient in children with neurofibromatosis type 1. J Comput Assist Tomogr 2003;27:681-6.

15. Eastwood JD, Fiorella DJ, MacFall JF, Delong DM, Provenzale JM, Greenwood RS. Increased brain apparent diffusion coefficient in children with neurofibromatosis type 1. Radiology 2001;219:354-8.

16. Ferraz-Filho JR, da Rocha AJ, Muniz MP, Souza AS, GoloniBertollo EM, Pavarino-Bertelli EC. Diffusion tensor MR imaging in neurofibromatosis type 1: expanding the knowledge of microstructural brain abnormalities. Pediatr Radiol 2012;42:449-54.

17. Wei CW, Guo G, Mikulis DJ. Tumor effects on cerebral white matter as characterized by diffusion tensor tractography. Can J Neurol Sci 2007;34:62-8.

18. Violante IR, Ribeiro MJ, Silva ED, Castelo-Branco M. Gyrification, cortical and subcortical morphometry in neurofibromatosis type 1: an uneven profile of developmental abnormalities. J Neurodev Disord 2013;5:3.

19. Schmahmann JD, Pandya DN. Disconnection syndromes of basal ganglia, thalamus, and cerebrocerebellar systems. Cortex 2008;44:1037-66.

20. Levine TM, Materek A, Abel J, O’Donnell M, Cutting LE. Cognitive profile of neurofibromatosis type 1. Semin Pediatr Neurol 2006;13:820.

21. Roy A, Roulin JL, Charbonnier V, Allain P, Fasotti L, Barbarot S, et al. Executive dysfunction in children with neurofibromatosis type 1: a study of action planning. J Int Neuropsychol Soc 2010;16:1056-63.

22. Grahn JA, Parkinson JA, Owen AM. The cognitive functions of the caudate nucleus. Prog Neurobiol 2008;86:141-55. 